\title{
THE EVALUATION OF THE REDUCTION OF SEISMIC RESPONSE OF ADJACENT STRUCTURES USING VISCOUS DAMPER JOINTS
}

\author{
Hamed Karbalay Malek', Kamal Emami² \\ 1 Department of Civil Engineering, Shabestar Branch, Islamic Azad University, Shabestar, Iran, e-mail: civil.eng. \\ hamed@gmail.com \\ 2 Department of Civil Engineering, Shabestar Branch, Islamic Azad University, Shabestar, Iran, e-mail: \\ kemami475@iaushab.ac.ir
}

Received: 2017.05.15

Accepted: 2017.08.01

Published: 2017.09.03

\begin{abstract}
This study examines the effects of common viscose damper on the behavior of adjacent reinforced concrete structures. For this purpose, three reinforced concrete buildings with 3, 5 and 7 floors and a regular plan were selected and were compared in two cases with and without viscous dampers at the seams. They are designed based on discussions of Buildings Regulations 2800 and the 6 and 9 issues of Iranian National Building Regulations. Those buildings that were under the analysis of accelerograms of Bam, Mangil and El Centro, are then analyzed with nonlinear modal time history. The accelerograms before applied to the structures are scaled based on the 2800 Regulations. Those buildings were modeled by SAP2000 finite element modeling software. Linear behavior of structural components of said structure and the non-linear behavior of viscous dampers were modeled. Finally, the seismic response of the buildings includes the base shear force, up to a maximum lateral acceleration of seismic classes. Classes for both with and without the viscous damper have been extracted and compared. The results showed the reduction in relative lateral displacement, maximum acceleration and base cut applied to a structure in the presence of viscous dampers between two structures. This decline is not even in the direction that the viscous damper is viewed as significant.
\end{abstract}

Keywords: viscous damper, drift, maximum acceleration, cutting foundations, reinforced concrete structure, seismic analysis.

\section{INTRODUCTION}

Earthquake risk is always lurking in any structure where they are prevalent. The consequences of this risk, depending on the physical effects caused by the structural failure, can be unpredictable. Braced Frames. braced and shear walls are both economic and effective to control deformation and adverse effects of weak earthquakes but do not have the desired behavior during severe earthquakes in these kinds of structure. Firstly, the stiffness of the structures is high and they tend to absorb more seismic forces. Second- ly, energy dissipation capacity due to the injuries sustained during the earthquake load resisting elements of reciprocating motion, (hysteresis), suffered severely and power dissipation is reduced as quickly in the next cycle.

Therefore, there is a vital need to waste energy dissipation during earthquakes so that its behavior under dynamic loading is not affected and is highly effective in terms of economic sense. Fluid viscous dampers are a means of energy loss incurred. Therefore, the amount of movement between two adjacent structures during an earthquake is of high importance. 
One way to reduce seismic retrofitting of structures in seismic lateral force is the use of dampers. During an earthquake, the structure receives a lot of energy. This is both kinetic and potential energy (strain) is applied to structure and it is absorbed or dissipated. If the structure is free of damping, its vibration will be continuous, but because there is damping in materials, vibration is reduced [1]. Input energy of structural earthquake statements introduced in the equation (1) becomes:

$$
E=E_{k}+E_{s}+E_{h}+E_{d}
$$

In the above equation earthquake input energy, $E_{k}$ is kinetic energy, $E_{s}$ is reversible strain energy in the elastic range, $E_{h}$ is wasted energy due to inelastic deformation and $\mathrm{E}_{\mathrm{d}}$ is wasted energy and is due to the additional damper.

Increased damping reduces the structural response (acceleration and change of location). Increasing the damping at low rotations (close to zero) has no effect on the amount of spectrum and the high rotations little effect on the acceleration replies. Two different philosophies for the design of earthquake-resistant structures exist [2]:

- (A) Designed such that the ductile deformation structures under severe earthquakes suffered substantial and dissipate seismic energy through the non-linear behavior.

- (B) Increasing the damping of structures with the use of mechanical dampers and earthquake energy dissipation without causing significant damage to structural components.

In the second type of design rather than energy flow and damage caused by deformations and vibration damper member amortized been written. The use of dampers in addition to accretion energy dissipation capability reduces the structural response to the earthquake and thus damage to non-structural components.

The base isolation systems, use of energy dissipation systems, have had a special place. An increase of damping is possible using various methods such as the flow soft metal, metal friction on the overall movement of a piston inside a slime or viscos-elastic environment with behavior in the same elastic material.

\section{DAMPING}

Due to the structural dynamic equation (1), in more traditional design methods, structures called damper are not observed. Therefore, by defining a new member in structures as a damper, where seismic energy dissipation factor enters into a building and applying it to buildings, construction can be optimized against a variety of dynamic loads caused by earthquakes [2].

Due to the dynamic nature of the earthquake and free body structure formula to move one degree of freedom system under dynamic load $P$ can be written:

$$
M \ddot{u}+C \dot{u}+K u=P(t)
$$

where: $\mathrm{M}$ - mass of the structure, $\mathrm{K}$ - structural stiffness, $\mathrm{C}-$ damping, $\mathrm{U}-$ displacement, Ù - Speed structures, Ü - structural acceleration, $\mathrm{P}-$ dynamic force structures.

To reduce the force exerted on the structure $\mathrm{U}$ value must be reduced, and the structure of short-term high vibration is prevented. It is obvious that by increasing the damping in equation (2) structural displacement is reduced.

The amount of displacement of structures (U) is:

$$
U=e^{-\xi \omega r}\left(A \cos \omega_{D} t+B \operatorname{Sin} \omega_{D} t\right)
$$

Two parameters have a major role in this equation: $\xi$ - the ratio of the actual damping coefficient to critical damping coefficient structures; $\omega$ - the natural frequency of the structure can be obtained from the equation $\omega=\sqrt{ } K / M$.

By increasing $\xi$ the maximum amount of $U$ is reduced, and by increasing $\omega$ the number of low volatility is reduced. Therefore, the applied force is reduced.

In equation (2), A and B are constant coefficients that are calculated due to the initial conditions. $\omega_{D}$ is the natural frequency due to damping and the amount of which:

$$
\omega_{D}=\omega \sqrt{1-\xi^{2}}
$$

Due to the amount of $\xi$ we have 3 types of structures:

1. cross-damping $\xi>1$,

2. critical damping $\xi=1$,

3. low damping $\xi<1$.

In recent years, new protective systems meant that any kind of influence on the building reduces the force of the earthquake. Since the dampers are used for earthquake energy dissipation factor, a brief explanation about the general types and a variety of damping systems and wasted energy were presented. 


\section{Viscous fluid Damper}

Fluid viscous damper is one of the energy absorbing systems when compared to their physical size have the ability to absorb high energy. Like friction dampers, the idea of dampers is taken from a car braking system. Cars Suspension uses a spring and a shock absorber that interact with each other, it absorbs the blows into the car and they waste their energy. If the columns of a structure are considered as a shock, by creating firmer springs (damper) next to them there can be a waste of energy into the structure by the earthquake [3].

The construction of viscous fluid dampers is generally made up of a piston and cylinder. The central piston moves with great speed in the chamber filled with fluid. The viscous fluid is compressed by the piston inside the cylinder with great speed. Therefore, almost all the kinetic energy is converted to pressure energy upstream. Given that in the piston, there is another cylinder in which high-pressure fluid can be pumped into the system, viscous liquid with little speed and its kinetic energy is exchanged between the two cylinders and the case becomes turbulent. This reciprocating motion causes a pressure difference, so much force that provides resistance to damper movement. A buffer fluid is silicone oil (oil containing oxygen and quartz). This oil also sustainable living and stay for a long time, nonflammable and non-toxic [4].

The generated force is dependent on the size and shape of the pores and the speed of movement. The damping forces are generated up to $90 \%$ off-stage driving forces by the production shift. This means that the damping forces had no effect on seismic forces leading to increased structural deformation. Addition of a damper fluid class structure reduces horizontal acceleration and lateral deformation of up to $50 \%$ and sometimes more [5].

These dampers, used to reduce vibrations, are used in large numbers across the world. In an effort to improve the performance of the damper, controllable models called semi-active damper viscose is provided. This type of damper is very similar to passive dampers. Semi-active viscous dampers that are equipped with an external ring pass fluid in the hydraulic cylinder piston that connect on each side. The ring has an adjustable through valve and controls the flow inside the damper. Thus, when the piston of the damp- er fluid pressure increases, it is able to generate larger dampening forces. Therefore, a significant amount of energy cannot dissipate from the earthquake [5].

Adding the dampers to the structure often will not lead to structural deformation and there will be a change in the structure itself. Viscous fluid dampers in many ways act as diagonal members of the structure. Dampers should be installed in adjacent classes to change any occurrence of uneveniness in the building [6-7].

Using these dampers is effective in designing structure systems, because the structure needs a predefined stiffness, to remain resistance to lateral forces and to remain stable. They can replace this extra stiffness and with energy-absorbing structures reduce vibration responses to other structural members remain in the elastic range.

Viscous damper provides a force that is always in front of the resistance structures. This force is proportional to the relative speed between the two ends of the damper:

$$
M \ddot{u}+C \dot{u}+K u=P(t)
$$

In which $\mathrm{F}$ is the damper force, $\mathrm{V}$ is the relative velocity of the piston and $\mathrm{C}$ is the damping coefficient. $\alpha$ damping coefficient, is a fixed number that is determined based on the diameter of the damper and aperture levels. Catalogue of viscous damper usually provided by manufacturers for several values of $\alpha . \alpha$ is much smaller than those normally selected for the design of earthquake-resistant design of the wind. $\alpha$ is exponential function of speed, which can have a value in the range of 0.3 to 1.95 [7].

Value for structural applications is proposed in the range of 0.3 to $1 . \alpha=1$ is called linear viscous damper the damper where the damper force is proportional to the relative velocity of the damper. Damper with $\alpha$ less than 1 is called nonlinear viscous damper that for a small relative speed, provides greater damping force.

Viscous damper force is dependent on speed. So that the maximum force of a damper in an earthquake always creates phase displacement of $\pi / 2$ and maximum speed comes at a time when the movement is zero. This is because of the advantages of the damper when the structure displacement effect caused by the earthquake is under intense internal forces; pressure applied to structure is not arrived, so better than other dampers can cut class, acceleration and base shear cut. Because of the specific form these devices and their location 
which is commonly braces are embedded. This means that. it can be easily embedded in existing structures or, replaced if necessary, after loading (earthquake).

There are several important advantages for the use of viscous dampers [5]:

1. The damper has no sensitivity to temperature changes and the lack of a solid construction and Bauschinger effect will not result in fatigue.

2. These dampers are the alternative to the method of isolating the base, because they are less expensive and easier to set up and run.

3. It can be used for new and old structures. This is very important in the restoration of historic buildings.

4. One of the characteristics of such dampers is their dynamics and they can adapt to the behavior of a structure plus their power to resist earthquake forces. Thus they are able to resist these forces.

5. The viscous damper is a sealed device, and this would tend to lower the atmospheric hazards that must endure friction dampers.

6. In the damper, a valve is used to adjust external energy only. Therefore, the damper does not require an external energy source and therefore are highly reliable.

7. Similar viscous damping equation is valid for all frequency levels.

Disadvantages:

1. Its life expectancy is low compared to the life of the structure.

2. Viscous dampers must be considered in a separate matrix. Attenuation coefficient matrix and if the dampers are an integral part of the process of solving the structural heterogeneity be difficult to disintegration of the system for analysis.

3. Due to low compression of viscous fluid, viscous damper is starting with a small kick.

\section{Related works}

For the first time viscous dampers were used in aerospace engineering to absorb the impacts caused by the launch or landing of aircraft. When the damper was used for their first structural engineering, the technology was fully developed over 35 years. Research and application of viscous dampers in civil engineering in 1990 coincided almost simultaneously with the end of the Cold War. The focus was on averaging the structural response of a seismic shake. The first use of viscous dampers for the purpose of seismic resistant design seismic was in 1993 in the Sanber Nsdino Medical Center in California. Viscous dampers added to the system helped to change places below 2.2 inches to 3 seconds remaining, and the structures will increase the effective period.

Dela Liera et al., (2005) analyzed the torsional balance of plan-asymmetric structures with frictional dampers. This investigation deals with the torsional balance of the earthquake response and design of elastic asymmetric structures with frictional dampers. Plan asymmetry leads to an uneven lateral deformation demand among structural members and to unbalanced designs with larger capacities in some resisting planes. Frictional dampers are capable of controlling lateraltorsional coupling by placing the so-called empirical center of balance (ECB) of the structure at equal distance from all edges of the building. This rule is developed for single-story systems with linear and inelastic behavior. However, recently obtained theoretical and experimental results demonstrate that this rule carries over to multistory structures. Results show that the peak displacement demand at the building edges and that of resisting planes equidistant from the geometric center may be similar if the damper is optimally placed. It is also shown that torsional amplification of the edge displacements of arbitrary asymmetric structures relative to the displacement of the symmetric counterparts are approximately bound by a factor of 2 . Furthermore, frictional dampers are equally effective in controlling lateral-torsional coupling of torsional flexible as well as stiff structures [5].

Lin et al. (2006) studied the behavior of concrete buildings with viscous dampers and RC walls in the style of shaking table tests. The results confirm the bracing damper system that we are using at any time that by changing the relative position of the installation method it is considered effective. In order to develop the performance in buildings as well as to develop medium and long-orders, a new design proposed that a single trend worked very well and states the ratio of viscous damping workload [8].

Behravesh and colleagues (2011) evaluated the seismic performance of structures with the effect of viscous dampers. They studied the 
viscous damper effect on steel frames with 3, 6 and 9 floors respectively. In this manner, each of the structures were braced, once without damper and with damper. Once a shift occurred, its effect on the structure was observed. Structural modeling was performed using SAP2000 software. The results show the effect of viscous dampers in the lower right lateral displacement class in particular frames baguette with more classes. In longer structures this amount has been reduced to about 54\% [9].

Chakhtab and colleagues evaluate the performance of a three-story concrete frame. It is modeled with finite element method and compared their results with the results of non-linear time history analysis. The results showed that using viscous dampers could affect the structure displacement response by up to $80 \%$ [10].

Mousavi et al. (2015) designed viscous dampers based on the vibration performance of steel frames. The results of time history analysis of structures under different risk levels records the accuracy of the estimation method. In all three models, the practice has achieved the desired performance improvement. In all cases, the building has gained acceptable performance improvements under earthquake conditions and real time is a good forecast of the behavior of the structure. This result demonstrates the high level of confidence due to the maximum error in the estimation method [11].

\section{METHODS AND MATERIALS}

\section{Gravity load profile models and instruments}

Models in this study are regular three-dimensional frameworks in the plan with 3,5 and 7 floors (Figure 1). Very significant structures $\mathrm{I}=$ 1.2 , are in an area with very high risk and $\mathrm{A}=$ 0.35 , with a ductile reinforced concrete moment frame structural system and the soil type II the average $\mathrm{R}=7$. Floors, ceiling height is 2.3 meters and structures are joists and blocks with two-way performance. Gravity loads in regular mode as symmetrical as shown in Figure 1 that the structures are imported.

As shown in Figure 1 loads on the structure of the project is in the form of live and the dead. The floor dead load and live load of $200 \mathrm{~kg}$ to 500 $\mathrm{kg}$ per square meter respectively, which is due to two-way system floor, adjacent beams transmitted in the frame.
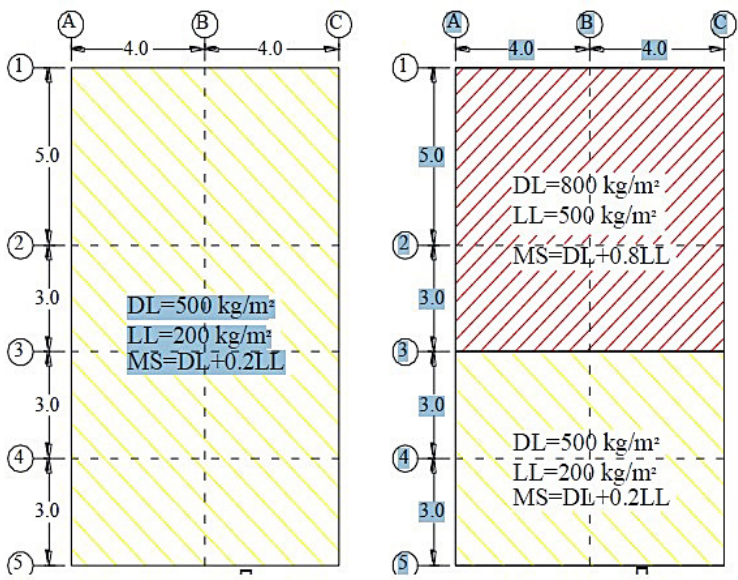

Fig. 1. Structural Plan with Dead Load (DL) and Live Loads (LL) on it
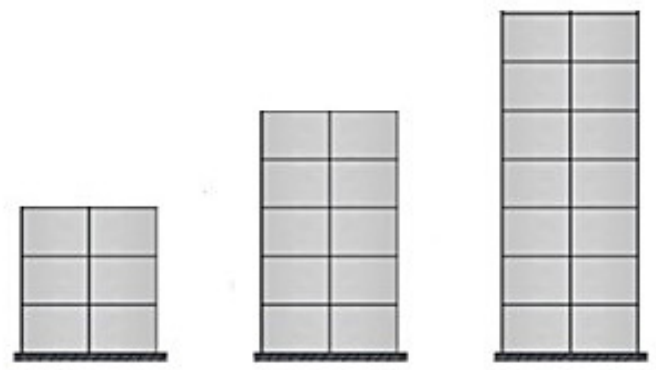

Fig. 2. View of one of frames along $X$ in the studied structures

Six types of structures have been used in this study and are presented in Table 1.

Each of these structures was analyzed once in the presence of a damper once regardless of the damper. Sections of beams and columns were presented in tables from Table 2 to Table 7. Selected properties of used material were described in Table 8.

\section{Used accelerograms and privacies to determine them}

Due to Iranian 2800 Regulations the earthquake records that are used to determine the effect of the Earth's motion should reflect the actual movement of the ground at the site of the building in an earthquake. To achieve this goal it is necessary to have at least three pairs of horizontal earthquake records belonging to different components and are registered with the following characteristics elected [2].

A) Accelerograms of earthquakes that satisfy the conditions in which they work: magnitude, distance to fault, seismic source mechanisms are taken into account. 
Table 1. Type of structural models examined in this study

\begin{tabular}{|c|c|c|c|}
\hline Structure type & $3-3$ & $3-7$ & $3-5$ \\
\hline Introduction & $\begin{array}{c}\text { 3-storey building in the vicinity } \\
\text { of 3 floors }\end{array}$ & $\begin{array}{c}\text { 3-storey building in the vicinity } \\
\text { of 7 floors }\end{array}$ & $\begin{array}{c}\text { 3-storey building in the vicinity } \\
\text { of 5 floors }\end{array}$ \\
\hline
\end{tabular}

Table 2. Levels of structural columns 3 floors

\begin{tabular}{|c|c|c|}
\hline Floors & Section dimension $(\mathrm{cm})$ anc & longitudinal reinforcement \\
\hline 1,2 & $45 \times 45$ & $16 \varnothing 20$ \\
\hline 3 & $40 \times 40$ & $12 \varnothing 20$ \\
\hline
\end{tabular}

Table 3. Beam section in the 3-storey structures

\begin{tabular}{|c|c|c|c|}
\hline Floors & Section dimension $(\mathrm{cm})$ & The upper reinforcement (Global) & Bottom reinforcement (Global) \\
\hline 1,2 & $40 \times 45$ & $3 \varnothing 22$ & $3 \varnothing 22$ \\
\hline 3 & $35 \times 40$ & $3 \varnothing 22$ & $3 \varnothing 22$ \\
\hline
\end{tabular}

Table 4. Levels of structural columns 5 floors

\begin{tabular}{|c|c|}
\hline Floors & Section dimension $(\mathrm{cm})$ and longitudinal reinforcement \\
\hline 1,2 & $60 \times 60 \quad 20 \varnothing 22$ \\
\hline 3,4 & $55 \times 55 \quad 20 \varnothing 22$ \\
\hline 5 & $50 \times 50 \quad 20 \varnothing 22$ \\
\hline
\end{tabular}

Table 5. Beam section in the 5-storey structures

\begin{tabular}{|c|c|c|c|}
\hline Floors & Section dimension $(\mathrm{cm})$ & The upper reinforcement (Global) & Bottom reinforcement (Global) \\
\hline 1,2 & $55 \times 60$ & $4 \varnothing 22$ & $4 \varnothing 22$ \\
\hline 3,4 & $50 \times 55$ & $4 \varnothing 22$ & $4 \varnothing 22$ \\
\hline 5 & $45 \times 50$ & $4 \varnothing 22$ & $4 \varnothing 22$ \\
\hline
\end{tabular}

Table 6. Levels of structural columns 7 floors

\begin{tabular}{|c|c|c|}
\hline Floors & Section dimension $(\mathrm{cm})$ an & longitudinal reinforcement \\
\hline 1,2 & $70 \times 70$ & $20 \varnothing 25$ \\
\hline 3,4 & $65 \times 65$ & $20 \varnothing 22$ \\
\hline 5,6 & $60 \times 60$ & $20 \varnothing 22$ \\
\hline 7 & $55 \times 55$ & $20 \varnothing 20$ \\
\hline
\end{tabular}

Table 7. Beam section in the 7-storey structures

\begin{tabular}{|c|c|c|c|}
\hline Floors & Section dimension $(\mathrm{cm})$ & The upper reinforcement (Global) & Bottom reinforcement (Global) \\
\hline 1,2 & $65 \times 70$ & $5 \varnothing 22$ & $5 \varnothing 22$ \\
\hline 3,4 & $60 \times 65$ & $5 \varnothing 22$ & $5 \varnothing 22$ \\
\hline 5,6 & $55 \times 60$ & $4 \varnothing 22$ & $4 \varnothing 22$ \\
\hline 7 & $50 \times 55$ & $4 \varnothing 22$ & $4 \varnothing 22$ \\
\hline
\end{tabular}

Table 8. Material properties of concrete in structural model

\begin{tabular}{|l|c|c|c|c|c|}
\hline & $\begin{array}{c}\text { Mass per unit } \\
\text { volume } \\
\mathrm{kg} / \mathrm{m}^{3}\end{array}$ & $\begin{array}{c}\text { Weight per unit } \\
\text { volume } \\
\mathrm{kg} / \mathrm{m}^{3}\end{array}$ & $\begin{array}{c}\text { Compressive strength } \\
\text { of concrete } \\
\mathrm{MPa}\end{array}$ & $\begin{array}{c}\text { Yield strength of longitudi- } \\
\text { nal reinforcement } \\
\mathrm{MPa}\end{array}$ & $\begin{array}{c}\text { Yield stress of } \\
\text { transverse bars } \\
\mathrm{MPa}\end{array}$ \\
\hline Concrete & 250 & 2500 & 24,5 & 392 & 295 \\
\hline
\end{tabular}



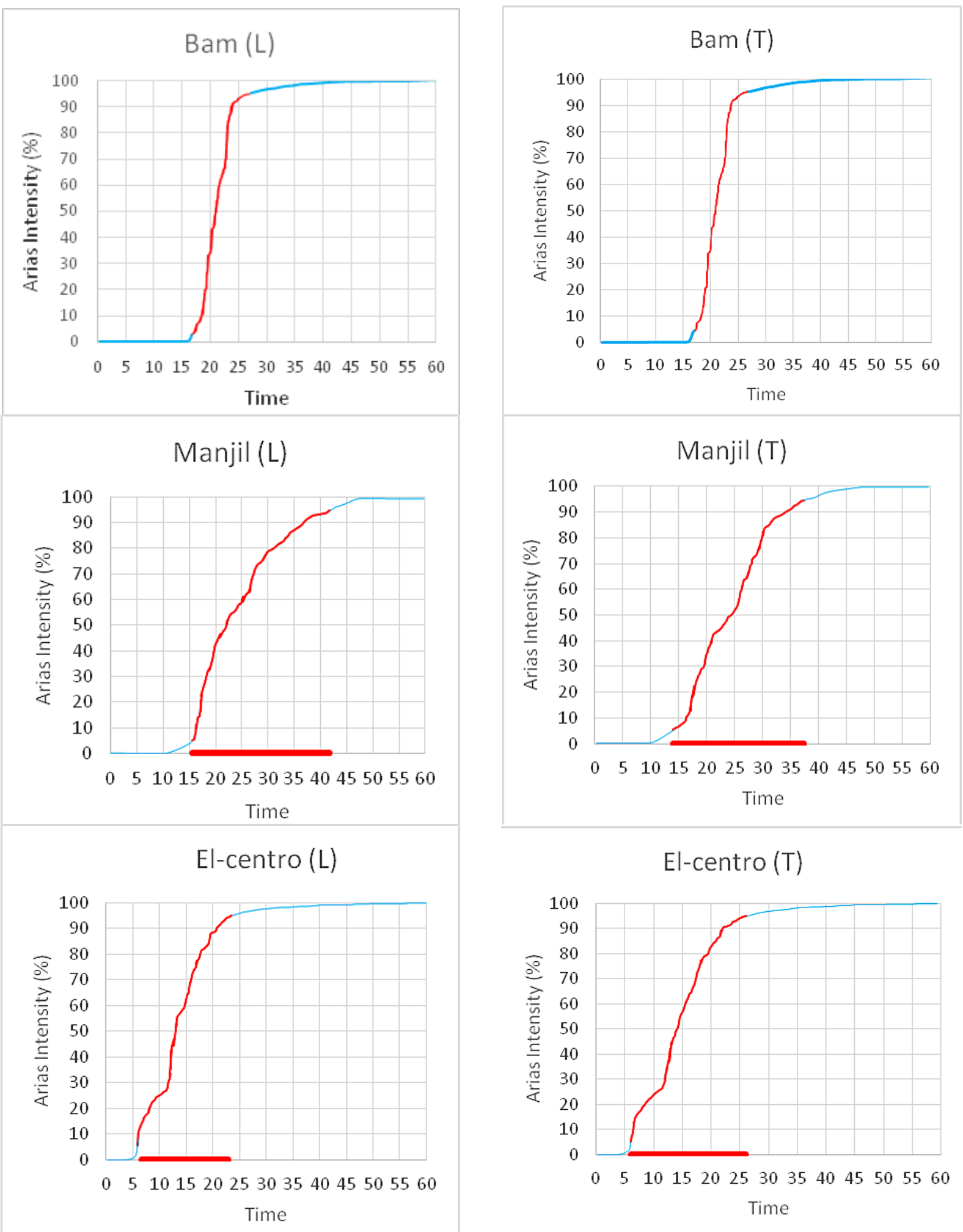

Fig. 2. Duration of strong ground motion (by way of energy distribution) in the records

Table 9. Used accelerograms characteristics

\begin{tabular}{|c|c|c|c|c|c|c|}
\hline No & Earthquake & Date & Location & Magnitude & $\mathrm{R}(\mathrm{km})$ & PGA(g) \\
\hline 1 & Bam & 1382 & Bam & 6.6 & 10 & 0.89 \\
\hline 2 & Manjil & 1369 & Manjil & 6.6 & 14.3 & 0.43 \\
\hline 3 & El-Centro & 1940 & - & 6.4 & 14.5 & 0.27 \\
\hline
\end{tabular}



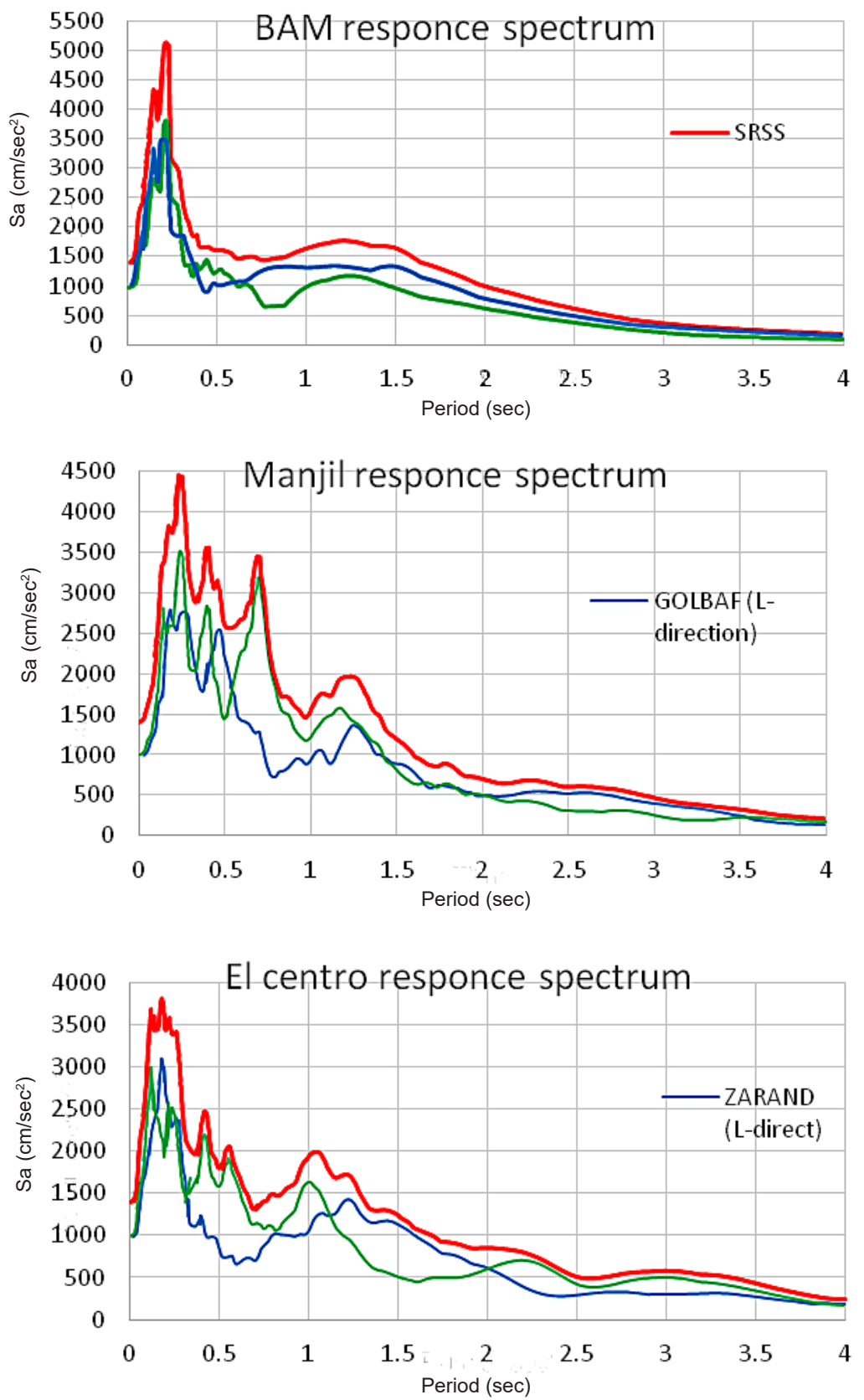

Fig. 3. Response spectra in this study

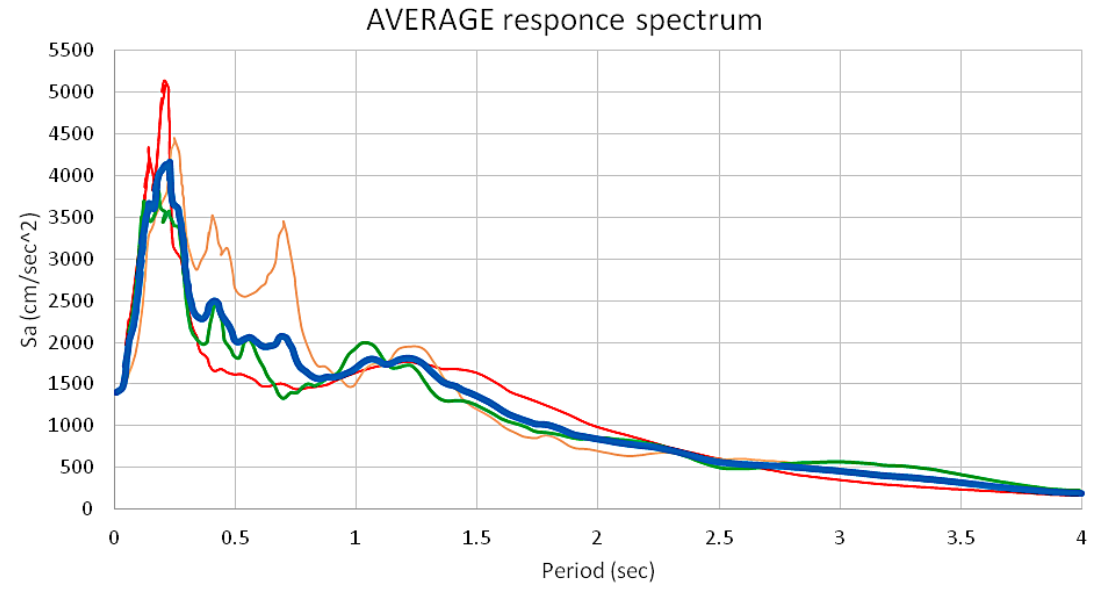

Fig. 4. Average of the three record earthquake response spectra 


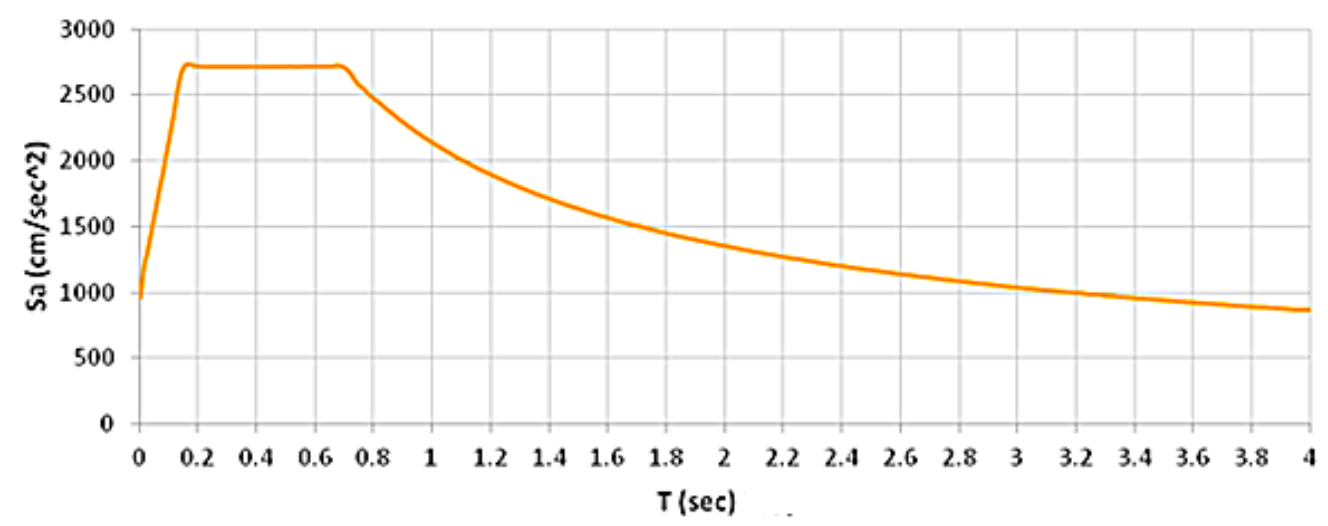

Fig. 5. Standard spectra of 2800 regulation

B) Builds of accelerograms have benefits in terms of geology, tectonicand seismology. Profile soil layers at the site of the building have similarities.

C) Duration of strong ground motion in accelerograms of at least 10 seconds or three times the fundamental period of construction, whichever is greater. Accelerograms duration of intense motion may be determined by valid methods, such as energy distribution.

The selected accelerograms should be compared using the following method:

A) All the accelerograms scaled in their maximum amount. This means that the maximum acceleration of all of them is equal to the gravitational acceleration.

B) Acceleration response spectra of each pair scaled accelerograms by setting the damping ratio at $5 \%$.
C) Response spectra combination of three pairs of records, $0.2 \mathrm{~T}$ and $1.5 \mathrm{~T}$ averaged in the range of rotations when compared with the spectrum of standard design. $T$ is fundamental period of the building is determined experimentally.

D) Determined scale factor, should be multiplied to the scaled accelerograms in paragraph (a) to be used in dynamic analysis.

Considering the above mentioned, accelerograms with magnitude 6 to 7 has been selected and the distance of the fault is between 15 to 25 $\mathrm{km}$ using 2800 Iran Regulations plans to land Type II scale. Accelerograms were downloaded from http://ngawest2.berkeley.edu. Accelerograms used in the nonlinear time history analysis are shown in Table 9.

First, the acceleration maps (raw accelerograms) were processed and corrected, such as modifying the baseline and modify the appro-

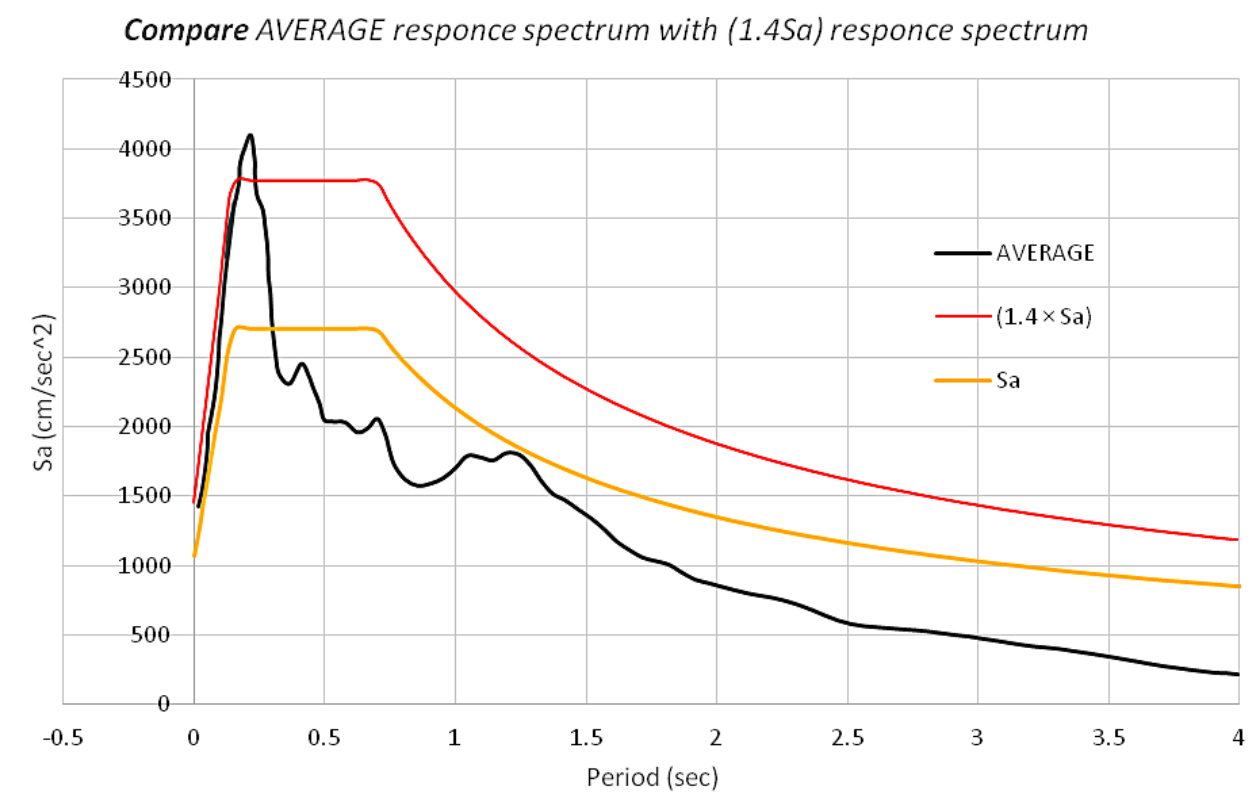

Fig. 6. Comparison of average accelerograms with 1.4 spectra of 2800 regulations 
Table 10. Accelerograms scale factor for all kinds of structures 3, 5 and 7 floors.

\begin{tabular}{|c|c|c|c|}
\hline Story & Period T $(\mathrm{sec})$ & $0.2 \mathrm{~T}$ 1.5T $(\mathrm{sec})$ & Scale factor \\
\hline 3 & 0.47 & $0.094-0.7$ & 0.14 \\
\hline 5 & 0.79 & $0.158-1.185$ & 0.112 \\
\hline 7 & 1.08 & $0.216-1.62$ & 0.139 \\
\hline
\end{tabular}

priate frequency band on them. Here, to determine the period of intense seismic maps, the proposed 2800 regulations energy distribution method is used. In this period, strong ground motion duration square integral acceleration in which a large share of the highly records are known to exist.

Square integral momentum is considered as between $5 \%$ and $95 \%$, of a period of strong ground motion. For this purpose, the following maps the Earth by the time the graph is drawn. The diagram below shows the duration of strong ground motion (by way of energy distribution) is given in the records.

In the following acceleration response spectra of each scaled accelerograms pair to be drawn with regard to the damping of $5 \%$ were shown. The response spectra of each pair is used and the whole combination unit is constructed by SRSS for each pair.

The combination of three couples is obtained by taking an average response spectra records and spectrum (spectrum average) compared with the standard spectrum.

Due to the 2800 standard spectra were plotted in $\mathrm{B}$, here to compare with average spectrum $\mathrm{Sa}$, the standard spectra should be multiplied in $g$ :

$$
S_{a}=g \cdot B=981 \times B \frac{\mathrm{cm}}{\sec ^{\wedge} 2}
$$

Average spectrum with 1.4 times the standard spectrum (not the whole standard layout) is compared. And scale factor is determined as the average values (average spectrum) in any case within the period of $0.2 \mathrm{~T}$ and $1.5 \mathrm{~T}$ ( $\mathrm{T}$ is fundamental period of oscillation) of not less than 1.4 times the standard range.
Due to the above figure and comparison of 1.4 standard spectra and the average of SRSS of accelerograms in $0.2 \mathrm{~T}$ and $1.5 \mathrm{~T}$, it is obvious that the average spectrum is under the standard. Considering the modifying factor of 2.15 for accelerograms, as it is shown in the following graph, the average spectrum is on the standard spectrum, and due to the main period of 3-, 5-, and 7- story structures and Figure 6, scale structures are obtained as Table 10.

\section{RESULTS}

In this section we present an analysis of history when each of the discussed models. To apply the effect of $\mathrm{P}-\Delta$ in each analysis, first the stiffness of the model is obtained by static analysis model, and then history analysis is used. This section is divided into three general classes, respectively, the maximum relative displacement, maximum acceleration of the center of mass on each floor and foundation structures has been split. As described in a previous part, three earthquake records have been used all of which equalized due to 2800 regulation. Then, according to the ninth issue, the structural response to earthquake forces is achieved on average. Viscous dampers used in this study has power of 0.5 , and the mass were 0.001 . In this study, non-linear damper performance is considered. Damper characteristics are given in Table 11 .

\section{Linear dynamic analysis}

In order to study the linear response of the structures time history analysis method has been used. Time history analysis used

Table 11. Characteristics of non-linear dampers

\begin{tabular}{|c|c|c|c|}
\hline Story & $\mathrm{K}(\mathrm{N} / \mathrm{mm})$ & $\mathrm{C}(\mathrm{N} \cdot \mathrm{sec} / \mathrm{mm})$ & $\alpha$ \\
\hline $3^{\text {rd }}$ & 2000 & 220 & 0.5 \\
\hline $2^{\text {nd }}$ & 2000 & 235 & 0.5 \\
\hline $1^{\text {st }}$ & 2000 & 300 & 0.5 \\
\hline
\end{tabular}


Table 12. Used seismic profile record

\begin{tabular}{|c|c|c|c|c|c|c|}
\hline No & Earthquake & Date & Location & Magnitude & $\mathrm{R}(\mathrm{km})$ & PGA(g) \\
\hline 1 & Bam & 1382 & Bam & 6.6 & 10 & 0.89 \\
\hline 2 & Manjil & 1369 & Manjil & 6.6 & 14.3 & 0.43 \\
\hline 3 & El-Centro & 1940 & - & 6.4 & 14.5 & 0.27 \\
\hline
\end{tabular}

Hilber-Hughes-Taylor integration method. In this analysis, the structural response is calculated using dynamic relationships in short time steps. The structural response is calculated under the stimulation of model based on at least three earthquake records. In this study, three accelerograms with the specifications set forth in the Table 12 is used.

In time history analysis component with larger PGA, structures that are of great importance in the study are entered. The analysis of structures listed under the record obtained based on the maximum acceleration mapping are presented in Table 12. The examination of each of the models will be discussed.

\section{Maximum relative displacement of stories}

According to the material presented in the previous section evaluation of the relative displacement of stories is very important. The study of the impact damper in use in buildings adjacent is realized. To investigate this effect, each of those types of models that have been introduced in the previous section will be discussed.

\section{3-7 Model}

The two structures are similar and their displacement with and without dampers is provided. The output is related to the software.

Results of displacement of 7-storey building nearby 3 floors with a damper is presented in Table 13. Displacement results for the 7-storey building adjacent to the 3 -story building with a damper is showed in Table 14. Displacement results for the 3-storey building adjacent to the 7 -story building with a damper is presented in Table 15. Table 16 shows displacement results for the 3-storey building adjacent to the 7-story building without damper. These results are presented also on Figure 7 and Figure 8.

\section{3-5 Model}

Displacement results for 5-story building adjacent to 3-story with damper is presented on
Table 17. Table 18 shows displacement results for 3 -story building adjacent to 5 -story with damper. Displacement results for 5-story building adjacent to 3-story without damper is presented in Table 19. Table 20 shows displacement results for 3-story building adjacent to 5-story without damper. These results are presented also on Figure 9 and Figure 10.

\section{3-3 Model}

Table 21 shows displacement results for 3 -story building adjacent to 3-story without damper. Displacement results for 3-story building adjacent to 3 -story with damper is presented in Table 22. These results are also presented in Figure 11.

\section{The maximum acceleration of the center of mass}

According to previous sections the maximum acceleration of the center of mass is one of the important parameters in the design of earthquakeresistant structures. In this section, the maximum acceleration (Manjil, El-Centro and Bam) is calculated and displayed. The average of the three accelerations with and without damper were displayed in each section individually.

\section{7-3 Model}

Table 23 shows maximum acceleration of the center of mass results for 7-story part without damper. Table 24 presents maximum acceleration of the center of mass results for 7-story part with damper. Table 25 shows maximum acceleration of the center of mass results for 3-story part without damper. Table 26 exhibits maximum acceleration of the center of mass results for 3-story part with damper. Figure 12 presents the average maximum acceleration of the center of mass results for 7-story part with and without damper. Figure 13 shows the average maximum acceleration of the center of mass results for 3-story part with and without damper. 
Table 13. Results of displacement of 7-storey building nearby 3 floors with a damper

\begin{tabular}{|c|c|c|c|c|}
\hline Story & Manjil & Bam & El Centro & Mean \\
\hline 1 & 0.1111 & 2.093063 & 0.104625 & 0.769595833 \\
\hline 2 & 0.177575 & 3.362488 & 0.16325 & 1.2344375 \\
\hline 3 & 0.222925 & 4.093363 & 0.1941875 & 1.503491667 \\
\hline 4 & 0.22655 & 4.265688 & 0.1994125 & 1.563883333 \\
\hline 5 & 0.217613 & 4.292763 & 0.188725 & 1.566366667 \\
\hline 6 & 0.188325 & 3.830463 & 0.1620625 & 1.393616667 \\
\hline 7 & 0.150888 & 3.134288 & 0.1296375 & 1.138270833 \\
\hline
\end{tabular}

Table 14. Displacement results for the 7-storey building adjacent to the 3-story building with a damper

\begin{tabular}{|c|c|c|c|c|}
\hline Story & Manjil & Bam & El Centro & Mean \\
\hline 1 & 0.04955 & 1.536888 & 0.055738 & 0.547392 \\
\hline 2 & 0.062038 & 2.048125 & 0.07295 & 0.727704 \\
\hline 3 & 0.047225 & 1.530013 & 0.055825 & 0.544354 \\
\hline
\end{tabular}

Table 15. Displacement results for the 3-storey building adjacent to the 7-story building with a damper

\begin{tabular}{|c|c|c|c|c|}
\hline Story & Manjil & Bam & El Centro & Mean \\
\hline 1 & 0.27775 & 5.232656 & 0.2615625 & 1.923989583 \\
\hline 2 & 0.443938 & 8.406219 & 0.408125 & 3.08609375 \\
\hline 3 & 0.557313 & 10.23341 & 0.48546875 & 3.758729167 \\
\hline 4 & 0.566375 & 10.66422 & 0.49853125 & 3.909708333 \\
\hline 5 & 0.544031 & 10.73191 & 0.4718125 & 3.915916667 \\
\hline 6 & 0.470813 & 9.576156 & 0.40515625 & 3.484041667 \\
\hline 7 & 0.377219 & 7.835719 & 0.32409375 & 2.845677083 \\
\hline
\end{tabular}

Table 16. Displacement results for the 3-storey building adjacent to the 7-story building without damper

\begin{tabular}{|c|c|c|c|c|}
\hline Story & Manjil & Bam & El Centro & Mean \\
\hline 1 & 0.123875 & 3.842219 & 0.139344 & 1.368479 \\
\hline 2 & 0.155094 & 5.120313 & 0.182375 & 1.81926 \\
\hline 3 & 0.118063 & 3.825031 & 0.139563 & 1.360885 \\
\hline
\end{tabular}

\section{Mean maximum Drift (7 story)}

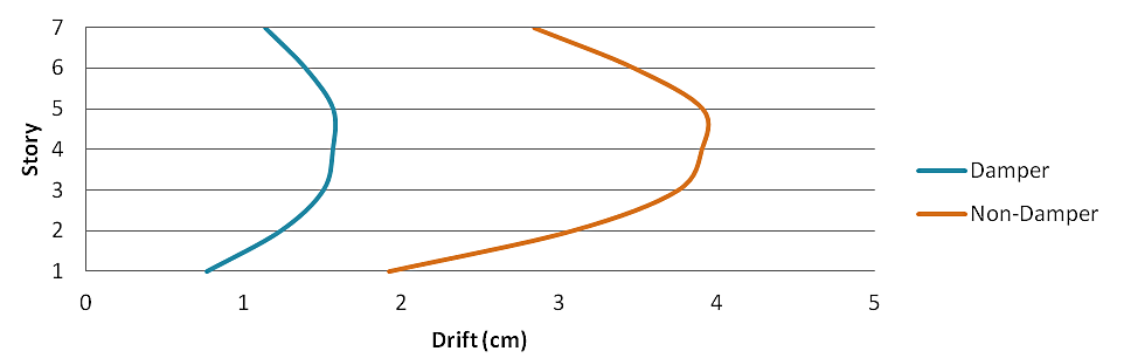

Fig. 7. The average of maximum displacement of three records for 7-story adjacent to 3-story

\section{Mean maximum Drift}

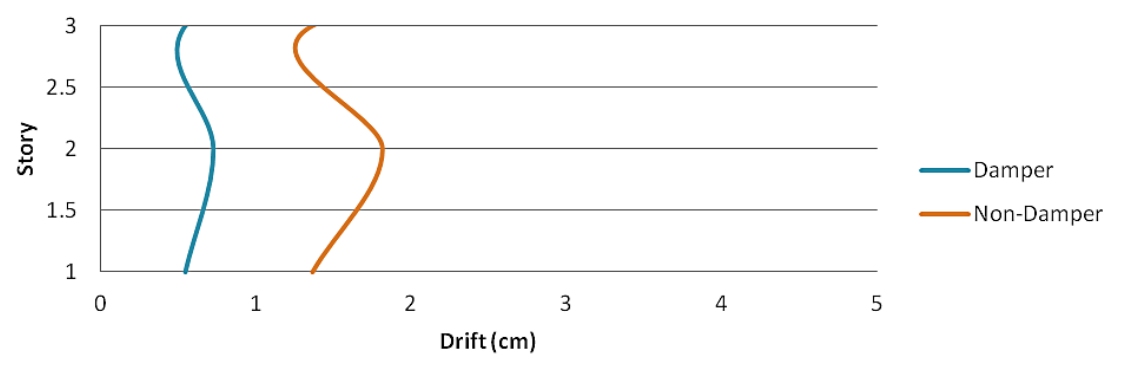

Fig. 8. The average of maximum displacement of three records for 3-story adjacent to 7-story

Table 17. Displacement results for 5-story building adjacent to 3-story with damper

\begin{tabular}{|c|c|c|c|c|}
\hline Story & Manjil & Bam & El Centro & Mean \\
\hline 1 & 0.131063 & 2.292581 & 0.169875 & 0.86450625 \\
\hline 2 & 0.190875 & 3.281494 & 0.25955625 & 1.243975 \\
\hline 3 & 0.210038 & 3.248719 & 0.28123125 & 1.2466625 \\
\hline 4 & 0.170888 & 2.410163 & 0.2298375 & 0.9369625 \\
\hline 5 & 0.107869 & 1.380919 & 0.145275 & 0.5446875 \\
\hline
\end{tabular}

Table 18. Displacement results for 5-story building adjacent to 3-story without damper

\begin{tabular}{|c|c|c|c|c|}
\hline Story & Manjil & Bam & El Centro & Mean \\
\hline 1 & 0.218438 & 3.820969 & 0.283125 & 1.44084375 \\
\hline 2 & 0.318125 & 5.469156 & 0.43259375 & 2.073291667 \\
\hline 3 & 0.350063 & 5.414531 & 0.46871875 & 2.077770833 \\
\hline 4 & 0.284813 & 4.016938 & 0.3830625 & 1.561604167 \\
\hline 5 & 0.179781 & 2.301531 & 0.242125 & 0.9078125 \\
\hline
\end{tabular}


Table 19. Displacement results for 3-story building adjacent to 5-story with damper

\begin{tabular}{|c|c|c|c|c|}
\hline Story & Manjil & Bam & El Centro & Mean \\
\hline 1 & 0.736406 & 10.30854 & 1.00216875 & 4.01570625 \\
\hline 2 & 0.093056 & 3.072188 & 0.109425 & 1.09155625 \\
\hline 3 & 0.238219 & 7.672538 & 0.276769 & 2.729175 \\
\hline
\end{tabular}

Table 20. Displacement results for 3-story building adjacent to 5-story without damper

\begin{tabular}{|c|c|c|c|c|}
\hline Story & Manjil & Bam & El Centro & Mean \\
\hline 1 & 1.227344 & 17.18091 & 1.67028125 & 6.69284375 \\
\hline 2 & 0.155094 & 5.120313 & 0.182375 & 1.819260417 \\
\hline 3 & 0.397031 & 12.78756 & 0.461281 & 4.548625 \\
\hline
\end{tabular}

\section{Mean maximum Drift (5story)}

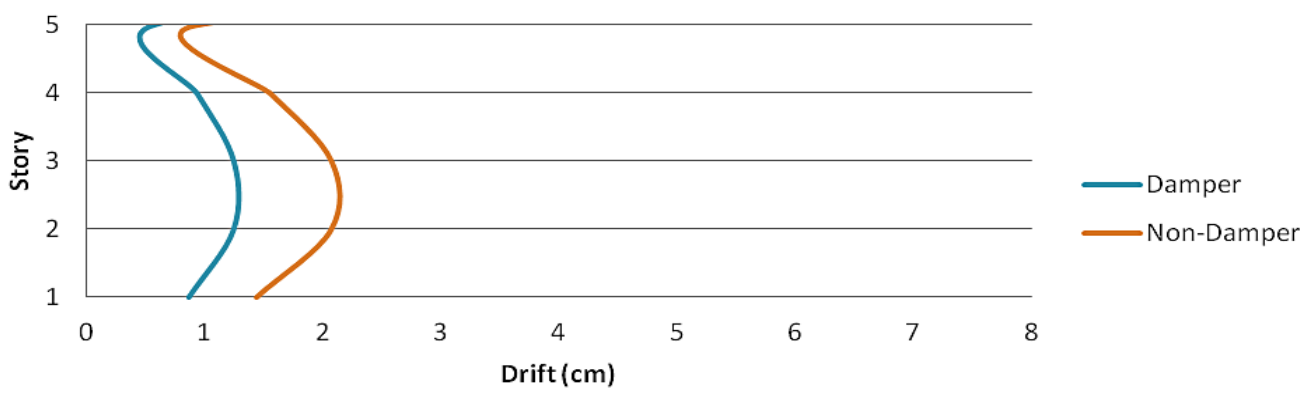

Fig. 9. the average of maximum displacement of three records for 5-story adjacent to 3-story

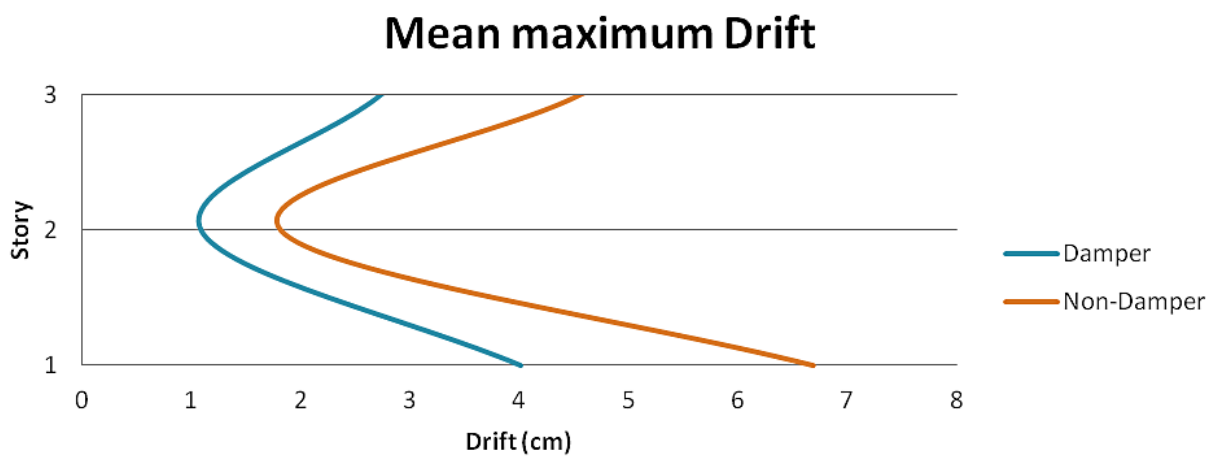

Fig. 10. Average of maximum displacement of three records for 3-story adjacent to 5-story

Table 21. Displacement results for 3-story building adjacent to 3-story without damper

\begin{tabular}{|c|c|c|c|c|}
\hline Story & Manjil & Bam & El Centro & Mean \\
\hline 1 & 0.27775 & 5.232656 & 0.2615625 & 1.923989583 \\
\hline 2 & 0.443938 & 8.406219 & 0.408125 & 3.08609375 \\
\hline 3 & 0.557313 & 10.23341 & 0.48546875 & 3.758729167 \\
\hline
\end{tabular}

Table 22. Displacement results for 3-story building adjacent to 3-story with damper

\begin{tabular}{|c|c|c|c|c|}
\hline Story & Manjil & Bam & El Centro & Mean \\
\hline 1 & 0.2222 & 4.186125 & 0.20925 & 1.539191667 \\
\hline 2 & 0.35515 & 6.724975 & 0.3265 & 2.468875 \\
\hline 3 & 0.44585 & 8.186725 & 0.388375 & 3.006983333 \\
\hline
\end{tabular}

\section{Mean maximum Drift}

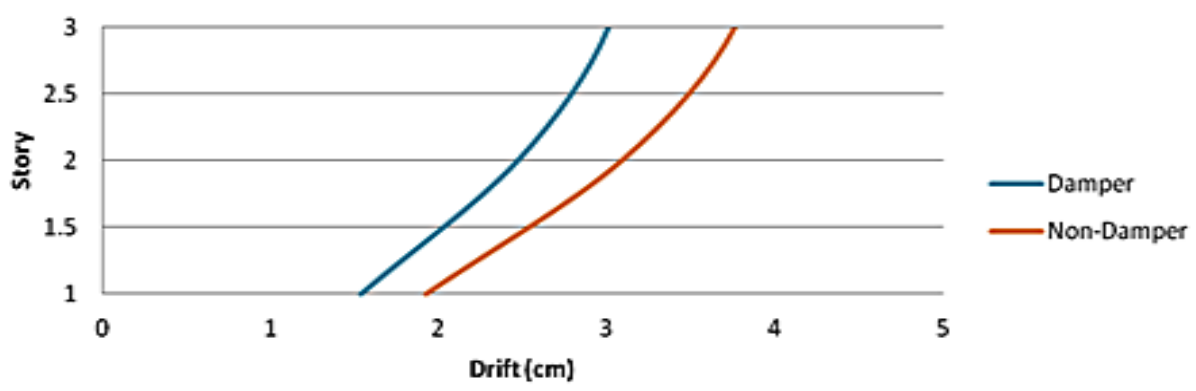

Fig. 11. Average of maximum displacement of three records for 3-story adjacent to 3-story 
Table 23. Maximum acceleration of the center of mass results for 7-story part without damper

\begin{tabular}{|c|c|c|c|c|}
\hline \multicolumn{5}{|c|}{ Acceleration non-damper } \\
story & Manjil & EL-Centro & Bam & mean \\
\hline 1 & 1.78808 & 2.8031 & 57.47479 & 20.68866 \\
\hline 2 & 4.04565 & 4.93421 & 98.52459 & 35.83482 \\
\hline 3 & 5.82087 & 6.45097 & 120.9507 & 44.4075 \\
\hline 4 & 6.72371 & 7.14912 & 148.7083 & 54.1937 \\
\hline 5 & 7.33115 & 7.30493 & 146.5756 & 53.73724 \\
\hline 6 & 7.97824 & 8.21385 & 156.9957 & 57.72926 \\
\hline 7 & 10.31619 & 9.39094 & 186.5167 & 68.74127 \\
\hline
\end{tabular}

Table 25. Maximum acceleration of the center of mass results for 3-story part without damper

\begin{tabular}{|c|c|c|c|c|}
\hline \multicolumn{5}{|c|}{ Acceleration non-damper } \\
\hline story & Manjil & EL-Centro & Bam & mean \\
\hline 1 & 1.6861 & 3.95833 & 80.9752 & 28.87321 \\
\hline 2 & 4.08966 & 7.53631 & 153.0573 & 54.89444 \\
\hline 3 & 5.84985 & 9.92367 & 239.3436 & 85.03905 \\
\hline
\end{tabular}

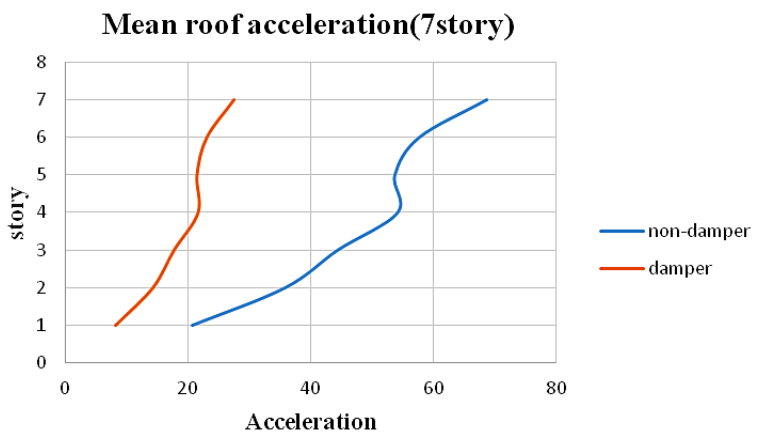

Fig. 12. The average maximum acceleration of the center of mass results for 7-story part with and without damper

\section{5-3 Model}

Table 27 shows maximum acceleration of the center of mass results for 5-story part without damper. Maximum acceleration of the center of mass results for 5-story part with damper is presented in Table 28. Table 29 shows maximum acceleration of the center of mass results for 3-story part without damper. Table 30 presents maximum acceleration of the center of mass results for 3 -story part with damper. Figure 14 shows the average maximum acceleration of the center of mass results for 5-story part with and without damper. Figure 15 presents the average maximum acceleration of the center of mass results for 3-story part with and without damper.
Table 24. Maximum acceleration of the center of mass results for 7-story part with damper

\begin{tabular}{|c|c|c|c|c|}
\hline \multicolumn{5}{|c|}{ Acceleration damper } \\
story & Manjil & EL-Centro & Bam & mean \\
\hline 1 & 0.786755 & 1.205333 & 23.27729 & 8.275463 \\
\hline 2 & 1.658717 & 1.973684 & 41.87295 & 14.33393 \\
\hline 3 & 2.357452 & 2.870682 & 54.4278 & 17.763 \\
\hline 4 & 3.02567 & 3.00263 & 63.94455 & 21.67748 \\
\hline 5 & 3.042427 & 3.14112 & 61.56177 & 21.4949 \\
\hline 6 & 3.590208 & 3.326609 & 65.15322 & 23.09171 \\
\hline 7 & 4.3328 & 4.225923 & 76.47184 & 27.49651 \\
\hline
\end{tabular}

Table 26. Maximum acceleration of the center of mass results for 3-story part with damper

\begin{tabular}{|c|c|c|c|c|}
\hline \multicolumn{5}{|c|}{ Acceleration damper } \\
\hline story & Manjil & EL-Centro & Bam & mean \\
\hline 1 & 0.741884 & 1.761457 & 34.81934 & 11.54928 \\
\hline 2 & 1.758554 & 3.278295 & 65.81466 & 21.95777 \\
\hline 3 & 2.33994 & 4.366415 & 101.721 & 34.01562 \\
\hline
\end{tabular}

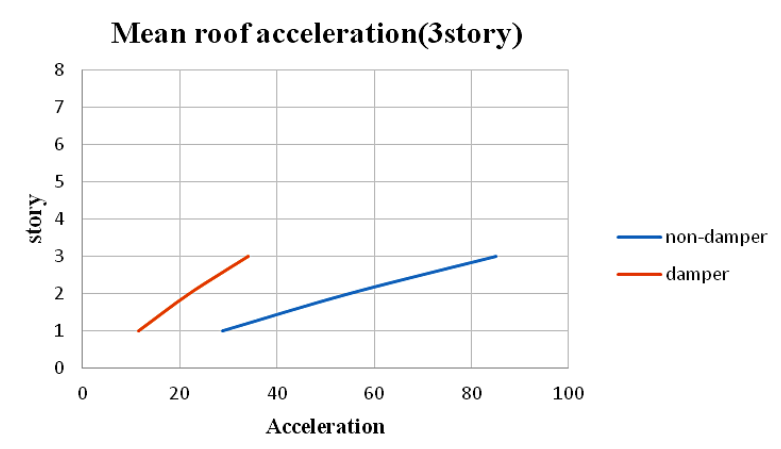

Fig. 13. The average maximum acceleration of the center of mass results for 3-story part with and without damper

\section{3-3 Model}

Table 31 shows maximum acceleration of the center of mass results for 3-story part without damper. Table 32 presents the appropriate results for 3 -story part with damper. Figure 16 shows the average maximum acceleration of the center of mass results for 3-story part with and without damper.

\section{Base shear of structures}

\section{7-3 model}

Figure 17 shows the base shear of structure for 7-story part with and without damper. Figure 18 presents the base shear of structure for 3-story part with and without damper. 
Table 27. Maximum acceleration of the center of mass results for 5-story part without damper

\begin{tabular}{|c|c|c|c|c|}
\hline \multicolumn{5}{|c|}{ Acceleration non-damper } \\
\hline story & Manjil & EL-Centro & Bam & mean \\
\hline 1 & 1.65647 & 3.14831 & 61.89578 & 22.23352 \\
\hline 2 & 3.63331 & 5.80471 & 126.6063 & 45.34811 \\
\hline 3 & 5.29447 & 8.35513 & 143.3589 & 52.33618 \\
\hline 4 & 6.06575 & 9.73448 & 141.127 & 52.30908 \\
\hline 5 & 7.64616 & 10.39264 & 180.8331 & 66.29064 \\
\hline
\end{tabular}

Table 29. Maximum acceleration of the center of mass results for 3-story part without damper

\begin{tabular}{|c|c|c|c|c|}
\hline \multicolumn{5}{|c|}{ Acceleration non-damper } \\
\hline story & Manjil & EL-Centro & Bam & mean \\
\hline 1 & 1.6861 & 3.95833 & 80.9752 & 28.87321 \\
\hline 2 & 4.08966 & 7.53631 & 153.0573 & 54.89444 \\
\hline 3 & 5.84985 & 9.92367 & 239.3436 & 85.03905 \\
\hline
\end{tabular}

\section{Mean roof acceleration(5story)}

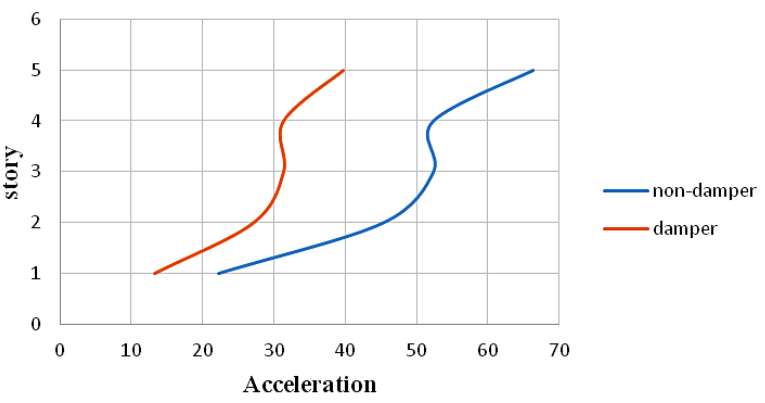

Fig. 14. The average maximum acceleration of the center of mass results for 5-story part with and without damper

Table 31. Maximum acceleration of the center of mass results for 3-story part without damper

\begin{tabular}{|c|c|c|c|c|}
\hline \multicolumn{5}{|c|}{ Acceleration non-damper } \\
\hline story & Manjil & EL-Centro & Bam & mean \\
\hline 1 & 1.6713 & 3.83178 & 80.89375 & 28.79894 \\
\hline 2 & 4.03183 & 7.44521 & 150.0507 & 53.84257 \\
\hline 3 & 5.74251 & 9.76216 & 231.9856 & 82.49674 \\
\hline
\end{tabular}

\section{5-3 model}

Figure 19 shows the base shear of structure for 5-story part with and without damper. Figure 20 presents the appropriate results for 3-story part.

\section{3-3 model}

Figure 21 shows the base shear of structure for 3-story part with and without damper.
Table 28. Maximum acceleration of the center of mass results for 5 -story part with damper

\begin{tabular}{|c|c|c|c|c|}
\hline \multicolumn{5}{|c|}{ Acceleration damper } \\
\hline story & Manjil & EL-Centro & Bam & mean \\
\hline 1 & 1.060141 & 1.983435 & 37.44695 & 13.34011 \\
\hline 2 & 2.216319 & 3.482826 & 79.12895 & 27.20887 \\
\hline 3 & 3.203154 & 5.389059 & 93.1833 & 31.40171 \\
\hline 4 & 3.942738 & 6.035378 & 88.91001 & 31.38545 \\
\hline 5 & 4.702388 & 6.547363 & 112.1165 & 39.77438 \\
\hline
\end{tabular}

Table 30. Maximum acceleration of the center of mass results for 3-story part with damper

\begin{tabular}{|c|c|c|c|c|}
\hline \multicolumn{5}{|c|}{ Acceleration damper } \\
\hline story & Manjil & EL-Centro & Bam & mean \\
\hline 1 & 1.079104 & 2.553123 & 51.01438 & 17.32393 \\
\hline 2 & 2.576486 & 4.785557 & 96.42612 & 32.93666 \\
\hline 3 & 3.50991 & 6.351149 & 149.5898 & 51.02343 \\
\hline
\end{tabular}

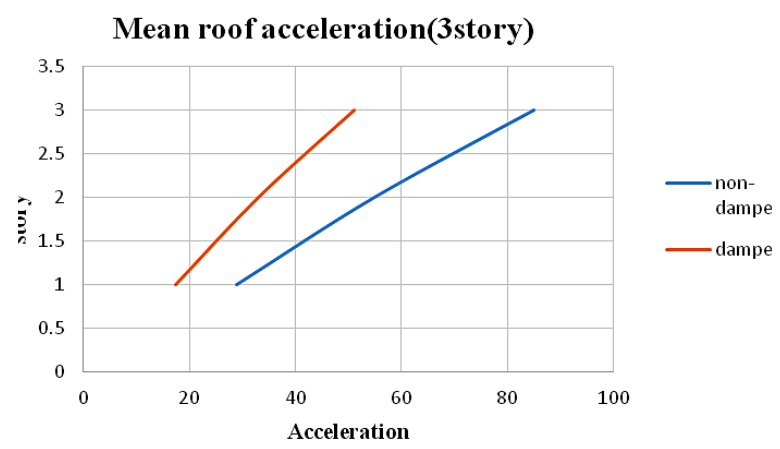

Fig. 15. The average maximum acceleration of the center of mass results for 3-story part with and without damper

Table 32. Maximum acceleration of the center of mass results for 3-story part with damper

\begin{tabular}{|c|c|c|c|c|}
\hline \multicolumn{5}{|c|}{ Acceleration damper } \\
\hline story & Manjil & EL-Centro & Bam & mean \\
\hline 1 & 1.571022 & 3.563555 & 73.20884 & 25.91905 \\
\hline 2 & 3.668965 & 6.700689 & 138.7969 & 48.45831 \\
\hline 3 & 5.196972 & 9.225241 & 220.3863 & 74.24707 \\
\hline
\end{tabular}

\section{CONCLUSION}

Using time history analysis, base shear response of structure in structures with and without damper were compared. As can be seen from the table, the structures 3, 5 and 7 floors had 22, 30 and 60 percent reduction in relative displacement, respectively. The results of this study showed that the ratio of periods of adjacent buildings is 


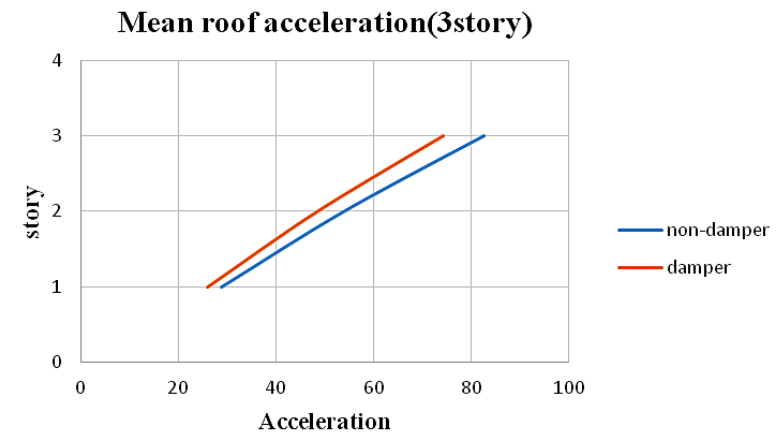

Fig. 16. The average maximum acceleration of the center of mass results for 3-story part with and without damper

For 7 Story

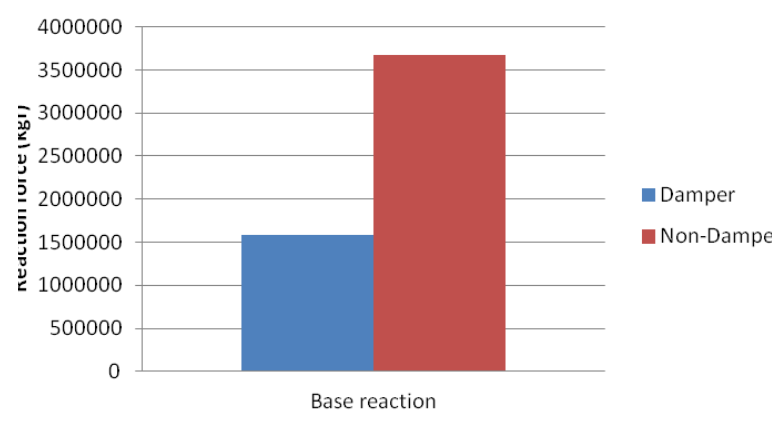

Fig. 17. The base shear of structure for 7-story part with and without damper

For 3 Story

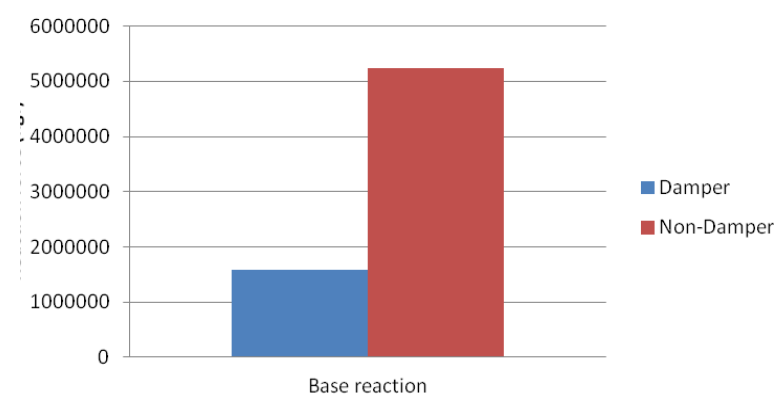

Fig. 18. The base shear of structure for 3-story part with and without damper

an important parameter in increasing the risk. The allowed value of 1.11 is proposed in regulations are not adequate and in some cases it is too conservative. Because structures with different periods produce different responses to earthquakes with frequency components, so it should be studied with care with considering the effect of earthquakes on the performance of structures. Another important consideration is the distance between and two structures and the increased the vulnerability of structures. Thus, widening the gap between two structures does not necessarily

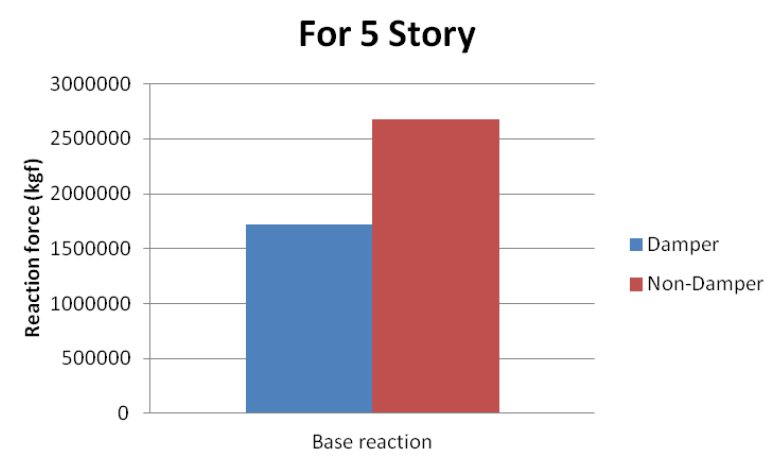

Fig. 19. The base shear of structure for 5-story part with and without damper

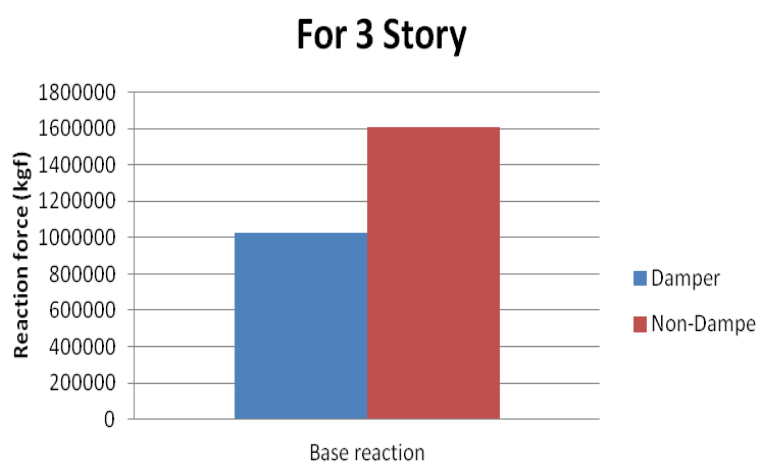

Fig. 20. The base shear of structure for 3-story part with and without damper

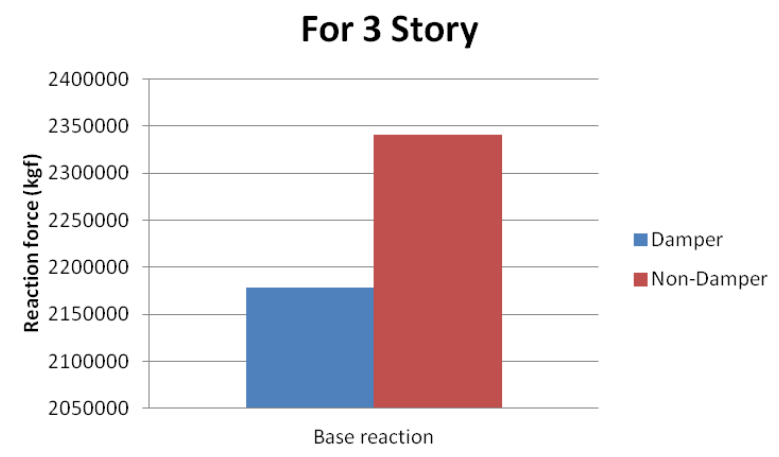

Fig. 21. The base shear of structure for 3-story part with and without damper

reduce the pass, in many cases increases the force of impact. Change in the amount of impact force, as well as changes in the level of vulnerability of neighboring structures, can be because of the near or distant frequency frequencies on structures. So hit phenomenon can enter transformed from linear to non-linear motion, resulting in the creation of cracks and reducing the level of performance of the structure [12-14].

According to the study it was found that the viscous damper between two adjacent structures can reduce the structural response. It was also 
observed that the effect of more viscous dampers with increased damping constant will not effective, but the location and pattern of installing them is also important. It was also observed that the optimal damping when using a uniform pattern of installation can be obtained on the fashion equivalent structures.

In the end it can be concluded that the observance of a safe distance between two adjacent structures can play an important role in making sustainable urban spaces. For the most seismic responses percent, corresponding to maximum acceleration is in the 7-3 model that we saw 53 percent reduction on each floor.

\section{REFERENCES}

1. Goel R.K. Effects of supplemental viscous damping on seismic response of asymmetric-plan systems. Earthquake Engineering \& Structural Dynamics, 1998, 27(2), 125-41.

2. Goel R.K. Passive control of earthquake-induced vibration in asymmetric buildings. In: Proceeding of 12th World Conference on Earthquake Engineering, 2000.

3. Goel R.K., Booker C.A. Effects of supplemental viscous damping on inelastic seismic response of asymmetric systems. Earthquake Engineering \& Structural Dynamics, 2001, 30(3), 411-30.

4. De La Llera J.C., Almazan J.L., Vial I., Ceballos V., Garcia M. Analytical and experimental response of asymmetric structures with friction and viscoelastic dampers. In: Proceeding of 13th World Conference on Earthquake Engineering 2004 Aug 1.

5. De la Llera J.C., Almazán J.L., Vial I.J. Torsional balance of plan-asymmetric structures with frictional dampers: analytical results. Earthquake Engineering \& Structural Dynamics, 2005, 34(9), 1089-108.

6. De La Llera J.C., Vial I.J., Almazan J.L., Fighetti E.C. Balanced design of asymmetric buildings with energy dissipation devices. In: Proceeding of the 8th National Conference on Earthquake Engineering, 2006.

7. Vial I.J., de la Llera J.C., Almazán J.L., Ceballos V. Torsional balance of plan-asymmetric structures with frictional dampers: experimental results. Earthquake Engineering \& Structural Dynamics, 2006, 35(15), 1875-98.

8. Lin T.K., Chen C.C., Chang K.C., Lin C.C,. Hwang J.S. Mitigation of micro vibration by viscous dampers. Earthquake Engineering and Engineering Vibration, 2009, 8(4), 569-82.

9. Behravesh A., Armaghani A., Akbarlou A., Sadeghi V., Evaluation of the effects of viscous dampers in performance of structures. In: The Sixth National Congress of Civil Engineering University of Semnan, Iran, 2012.

10. Charkhtab M., Estekanchi H., Using last time method in the optimal design of viscous dampers based on the seismic performance of steel frames. In: The Fifth National Congress of Civil Engineering, Ferdowsi University of Mashhad, Iran, 2014.

11. Mousavi S., Ziaifar M., laboratory studies and determine the behavioral features of Voskevaz damper axial contraction. In: The Tenth International Congress of Civil Engineering, Tabriz, Tabriz University, 2015.

12. Mousanezahad T., Pourzeinali S., Seismic monitoring tall buildings using semi-active viscous dampers. In: The Fourth National Congress on Civil Engineering, Tehran University, 2011.

13. Mirseifi H., Azhdari M., Ghalenoyi M., 4 and 8-storey steel buildings equipped with friction damper analysis using Abaqus software. In: The Sixth National Congress of Civil Engineering, University of Semnan, 2011.

14. Mansouri M., Nasseri H., Sarvemoghadam A., Laboratory examination and analysis of the distribution of Voskevaz damper on the behavior of asymmetric structures. Journal of Civil Engineering and Surveying, Islamic Azad University, Science and Research Branch, 2012. 